\title{
GAMBARAN PENGETAHUAN IBU TENTANG IMUNISASI PILIHAN DI WILAYAH KERJA PUSKESMAS PEMBANTU SEKELOA KELURAHAN SIDOREJO HILIR
}

\author{
Nova Linda Rambe \\ Universitas Imelda Medan, Indonesia
}

\begin{tabular}{|c|c|}
\hline Article Info & ABSTRACT \\
\hline Article history: & $\begin{array}{l}\text { There are still many mothers who do not understand and know about the } \\
\text { immunization options. Immunization of choice is a non-government }\end{array}$ \\
\hline Received Sep 25, 2019 & immunization that is useful for preventing various kinds of infectious \\
\hline Revised Sep 26, 2020 & diseases. The aim is to describe the knowledge of mothers about selected \\
\hline Accepted Sep 28, 2020 & $\begin{array}{l}\text { immunizations in the working area of the Hiligodu Ombolata Puskesmas. In } \\
\text { this study, using a descriptive research design with a population of } 62 \text { people }\end{array}$ \\
\hline Keywords: & $\begin{array}{l}\text { and a sample of } 62 \text { people with the total population technique. The } \\
\text { instrument used is a questionnaire. Based on the results of this study, it } \\
\text { shows that of the } 62 \text { respondents, the majority of the respondents with less }\end{array}$ \\
\hline Knowledge & knowledge were $37(59.68 \%)$ and the minority of respondents with good \\
\hline Immunization of choice & $\begin{array}{l}\text { knowledge were } 10(16.12 \%) \text {. After conducting the research it was } \\
\text { concluded that the knowledge of mothers about recommended immunization } \\
\text { was still lacking. It is hoped that mothers with toddlers should be more active } \\
\text { in seeking information about selected immunizations through health workers, } \\
\text { electronic media, mass media and print media. }\end{array}$ \\
\hline
\end{tabular}

This is an open access article under the CC BY-SAlicense.
Corresponding Author:
Nova Linda Rambe,
Program Studi S1 Kebidanan,
Universitas Imelda Medan,
J1. Bilal No. 52 Kelurahan Pulo Brayan Darat I Kecamatan Medan Timur, Medan - Sumatera Utara.
Email: rambenovalinda@gmail.com

\section{INTRODUCTION}

Laporan United Nations Children's Fund (UNICEF) yang dikeluarkan terakhir menyebutkan bahwa 27 juta anak balita dan 40 juta ibu hamil di seluruh dunia masih belum mendapatkan layanan imunisasi rutin. Akibatnya, penyakit yang dapat dicegah oleh vaksin ini diperkirakan menyebabkan lebih dari dua juta kematian tiap tahun. Hampir seperempat dari 130 juta bayi yang lahir tiap tahun tidak diimunisasi agar terhindar dari penyakit anak yang umum. Vaksin telah menyelamatkan jutaan jiwa anak-anak dalam tiga dekade terakhir, namun masih ada jutaan anak lainnya yang tidak terlindungi dengan imunisasi. Survei dilakukan World Health Organization (WHO) menunjukkan bahwa dibeberapa daerah angka imunitas kurang dari 56\%. Tiga tahun sebelumnya angka imunitas mencapai 70\%. Hal ini menunjukkan turunnya layanan kesehatan di beberapa daerah miskin. ("Progress for Children" Report no 3, September 2009).

Di tingkat Association South East Asean Nation (ASEAN, 2015), Indonesia misalnya angka kematian bayinya 4.809, kelahiran hidup yaitu hampir 5 kali lipat dibandingkan dengan angka kematian bayi di Malaysia, 2 kali dibandingkan dengan Thailand dan 1,3 kali dibandingkan dengan Philipina sekitar 57\% kematian bayi tersebut terjadi pada bayi berumur dibawah satu bulan dan utamanya disebabkan oleh campak, selain itu adalah gangguan perinatal, infeksi saluran pernapasan akut, diare, malaria dan Bayi Berat Lahir Rendah (BBLR), 40\% disebabkan oleh hipotermi, asfiksia karena prematuritas, dan trauma persalinan. 
Rata-rata imunisasi di Indonesia pada tahun 2005 hanya 72\%. Artinya, angka dibeberapa daerah sangat rendah. Ada sekitar 2.400 anak di Indonesia meninggal setiap hari termasuk yang meninggal karena sebab-sebab yang seharusnya dapat dicegah, misalnya tubercolosis, campak.

Pengetahuan seorang ibu akan mempengaruhi status imunisasinya. Masalah pegertian dan pemahaman ibu dalam program imunisasi bayinya tidak akan menjadi halangan yang besar jika pengetahuan yang memadai tentang hal itu diberikan. Pengetahuan ibu tentang imunisasi akan membentuk sikap positif terhadap kegiatan imunisasi. Dengan pengetahuan baik yang ibu miliki maka kesadaran untuk mengimunisasikan bayi akan meningkat yang mempengaruhi status imunisasi (M. Ali, 2008).

Ada beberapa hal yang berkaitan dengan penelitian ini yakni, Jenis-jenis imunisasi dan jadwal pemberian imunisasi. Adapun jenis imunisasi yakni imunisasi HiB, imunisasi Influenza, imunisasi Pneumokokus, imunisasi Meales Mumps Rubela (MMR), Tipoid, Hepatitis A, Varisela. Adapun jadwal menurut kamus besar Bahasa Indonesia adalah pembagian waktu berdasarkan rencana pengaturan urutan kerja daftar atau tabel kegiatan atau rencana kegiatan dengan pembagian waktu pelaksanaan yang terperinci. Sedangkan pengertian penjadwal adalah cara menjadwalkan atau memasukan kedalam jadwal. (Anonim 2012).

Pada keadaan tertentu imunisasi tidak dapat dilaksanakan sesuai dengan jadwal yang sudah disepakati. Keadaan ini tidak merupakan hambatan untuk melanjutkan imunisasi. Vaksin yang sudah diterima oleh anak tidak menjadi hilang manfaatnya tetapi tetap sudah menghasilkan respon imunologis sebagaimana yang diharapkan. (Sudarti, 2010).

Berdasarkan survey awal yang di lakukan di wilayah kerja puskesmas Pembantu Sekeloa Kelurahan Sidorejo Hilir, ibu-ibu yang mempunyai balita ada 62 orang, dan jumlah balita 153 orang dan yang mendapat imunisasi pilihan hanya 17 orang, sementara yang belum mendapat 136 orang. Berdasarkan data diatas, maka penulis tertarik untuk meneliti "Gambaran Pengetahuan Ibu Tentang Imunisasi Pilihan di wilayah kerja puskesmas pembantu Sekeloa Kelurahan Sidorejo Hilir”.

\section{RESEARCH METHOD}

Penelitian ini menggunakan desain penelitian survey deskriptif untuk mengetahui pengetahuan ibu tentang imunisasi pilihan. Penelitian dilakukan di Wilayah Kerja Puskesmas Sekeloa Kelurahan Sidorejo Hilir sebanyak 62 orang. Pengambilan sampel penelitian dilakukan secara puerposive sampling. Subjek penelitian ini memiliki kriteria inklusi yaitu ibu yang mempunyai anak 0-2 tahun, ibu bisa sehat jasmani dan rohani, anak tidak ada kelainan kongenital. Instrumen yang digunakan adalah lembar kuesioner. Analisis data dilakukan menggunakan persentase.

\section{RESULTS AND ANALYSIS}

\subsection{Hasil}

Berdasarkan penelitian yang dilakukan terhadap 62 orang responden tentang judul "Gambaran Pengetahuan Ibu Tentang Imunisasi Pilihan Di Wilayah Kerja Pembantu Sekeloa Kelurahan Sidorejo Hilir" maka di dapat hasil sebagai berikut:

Tabel 1. Distribusi Karakteristik Responden

\begin{tabular}{clcc}
\hline No. & Karakteristik & f & \% \\
\hline 1 & Umur & 59 & 95 \\
& $>35$ tahun & 3 & 5 \\
& $20-30$ tahun & 0 & 0 \\
\hline & $<20$ tahun & & \\
\hline 2 & Pekerjaan & 6 & 9,68 \\
& PNS & 26 & 41,93 \\
& Wiraswasta & 30 & 48,39 \\
& Tani & & \\
& Pendidikan & 10 & 16,13 \\
& Sarjana & 20 & 32,26 \\
& SMP/SMA & 32 & 51,61 \\
\hline & Tidak sekolah/SD & & \\
\hline 4 & Sumber Informasi & 12 & 19,35 \\
& Petugas Kesehatan & 30 & 48,39 \\
& Keluarga dan lingkungan & 20 & 32,26 \\
\hline & Media Elektronik &
\end{tabular}

Berdasarkan table di atas dapat di lihat bahwa mayoritas umur responden $>30$ tahun sebanyak 59 orang (95\%), minoritas umur responden 20-30 tahun sebanyak 3 orang (5\%). Mayoritas pekerjaan responden Tani sebanyak 30 orang (48,39\%), minoritas pekerjaan responden Pegai Negeri Sipil sebanyak 6 orang (9,68\%). Mayoritas pendidikan responden Tidak bersekolah/SD sebanyak 32 orang (51,61\%), minoritas pendidikan responden Perguruan Tinggi sebanyak 10 orang (16,12\%). Mayoritas responden memperoleh 
sumber informasi dari keluarga/lingkungan sebanyak 30 orang $(48,39 \%)$, minoritas memperoleh informasi dari tenaga kesehatan sebanyak 12 orang $(19,35 \%)$.

Tabel 2. Pengetahuan Responden

\begin{tabular}{cccc}
\hline No. & Tingkat Pengetahuan & Frekuensi (f) & Presentase $(\boldsymbol{\%})$ \\
\hline 1 & Baik & 10 & 16,12 \\
\hline 2 & Cukup & 15 & 24,20 \\
\hline 3 & Kurang & 37 & 59,68 \\
\hline & Total & $\mathbf{6 2}$ & $\mathbf{1 0 0}$ \\
\hline
\end{tabular}

Dari tabel diatas dapat diketahui bahwa mayoritas tingkat pengetahuan responden berpengetahuan kurang sebanyak 37 orang $(43,54 \%)$ dan minoritas responden berpengetahuan baik sebanyak 10 orang $(16,12 \%)$.

Tabel 3. Distribusi Pengetahuan Responden Berdasarkan Umur

\begin{tabular}{|c|c|c|c|c|c|c|c|c|c|}
\hline \multirow{3}{*}{ No } & \multirow{3}{*}{ Umur } & \multicolumn{6}{|c|}{ Pengetahuan } & \multirow{2}{*}{\multicolumn{2}{|c|}{ Jumlah }} \\
\hline & & \multicolumn{2}{|c|}{ Baik } & \multicolumn{2}{|c|}{ Cukup } & \multicolumn{2}{|c|}{ Kurang } & & \\
\hline & & f & $\%$ & $\mathbf{f}$ & $\%$ & $\mathbf{f}$ & $\%$ & $\mathbf{F}$ & $\%$ \\
\hline 1 & $>35$ tahun & 9 & 14,52 & 15 & 24,20 & 35 & 56,45 & 59 & 95,17 \\
\hline 2 & 20-30 tahun & 1 & 1,61 & 0 & 0 & 2 & 3,22 & 3 & 4,83 \\
\hline 3 & $<20$ tahun & 0 & 0 & 0 & 0 & 0 & 0 & 0 & 0 \\
\hline & Jumlah & 10 & 16,13 & 15 & 24,20 & 37 & 59,67 & 62 & 100 \\
\hline
\end{tabular}

Berdasarkan tabel 3 di atas dapat di lihat bahwa mayoritas responden yang berpengetahuan kurang umur > 30 tahun sebanyak 35 orang $(56,45 \%)$ dan minoritas responden berpengetahuan baik umur 20-30 tahun sebanyak 1 orang $(1,61 \%)$.

Tabel 4. Distribusi Pengetahuan Responden Berdasarkan Pekerjaan

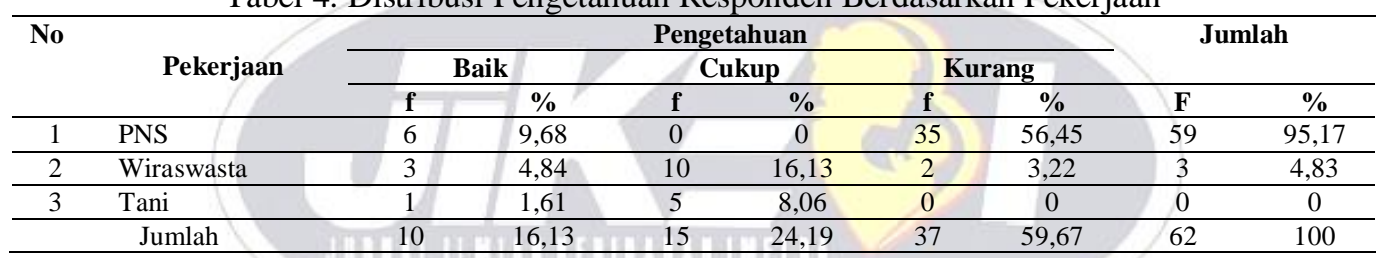

Berdasarkan tabel diatas dapat dilihat bahwa mayoritas responden yang berpengetahuan kurang adalah Petani sebanyak 24 orang $(38,71 \%)$ dan minoritas responden berpengetahuan baik adalah Petani sebanyak 1 orang $(1,61 \%)$.

Tabel 5. Distribusi Pengetahuan Responden Berdasarkan Pendidikan

\begin{tabular}{|c|c|c|c|c|c|c|c|c|c|}
\hline \multirow[t]{3}{*}{ No } & \multirow{3}{*}{ Pendidikan } & \multicolumn{6}{|c|}{ Pengetahuan } & \multirow{2}{*}{\multicolumn{2}{|c|}{ Jumlah }} \\
\hline & & \multicolumn{2}{|c|}{ Baik } & \multicolumn{2}{|c|}{ Cukup } & \multicolumn{2}{|c|}{ Kurang } & & \\
\hline & & f & $\%$ & f & $\%$ & f & $\%$ & $\mathbf{F}$ & $\%$ \\
\hline 1 & Sarjana & 7 & 11,29 & 3 & 4,84 & 0 & 0 & 10 & 16,13 \\
\hline 2 & SMP/SMA & 3 & 4,84 & 10 & 16,13 & 7 & 11,29 & 20 & 32,26 \\
\hline 3 & Tidak sekolah/SD & 0 & 0 & 2 & 3,22 & 30 & 48,39 & 32 & 51,61 \\
\hline & Jumlah & 10 & 16,13 & 15 & 24,19 & 37 & 59,67 & 62 & 100 \\
\hline
\end{tabular}

Berdasarkan tabel diatas dapat dilihat bahwa mayoritas responden yang berpengetahuan kurang adalah berpendidikan SD sebanyak 30 orang $(48,39 \%)$ dan minoritas responden berpengetahuan cukup adalah SMP/SMA sebanyak 3 orang $(4,84 \%)$.

Tabel 6. Distribusi Pengetahuan Responden Berdasarkan Sumber Informasi

\begin{tabular}{|c|c|c|c|c|c|c|c|c|c|}
\hline \multirow[t]{3}{*}{ No } & \multirow[t]{3}{*}{ Sumber Informasi } & \multicolumn{6}{|c|}{ Pengetahuan } & \multirow{2}{*}{\multicolumn{2}{|c|}{ Jumlah }} \\
\hline & & \multicolumn{2}{|c|}{ Baik } & \multicolumn{2}{|c|}{ Cukup } & \multicolumn{2}{|c|}{ Kurang } & & \\
\hline & & $\mathbf{f}$ & $\%$ & f & $\%$ & f & $\%$ & $\mathbf{F}$ & $\%$ \\
\hline 1 & Petugas Kesehatan & 10 & 16,13 & 2 & 3,22 & 0 & 0 & 10 & 16,13 \\
\hline 2 & Keluarga/lingkungan & 0 & 0 & 4 & 6,45 & 26 & 41,94 & 20 & 32,26 \\
\hline 3 & Media Elektronik & 0 & 0 & 9 & 14,52 & 11 & 17,74 & 32 & 51,61 \\
\hline & Jumlah & 10 & 16,13 & 15 & 24,19 & 37 & 59,68 & 62 & 100 \\
\hline
\end{tabular}

Berdasarkan tabel diatas dapat dilihat bahwa mayoritas responden yang berpengetahuan kurang adalah berpendidikan SD sebanyak 30 orang $(48,39 \%)$ dan minoritas responden berpengetahuan cukup adalah SMP/SMA sebanyak 3 orang (4,84\%).

\subsection{Pembahasan}

Berdasarkan hasil penelitian diketahui bahwa mayoritas tingkat pengetahuan responden berpengetahuan kurang sebanyak 37 orang $(59,68 \%)$ dan minoritas responden berpengetahuan baik sebanyak 
10 orang $(16,12 \%)$. Menurut (Notoadmodjo, 2008), bahwa pengetahuan merupakan hasil tahu dan terjadi setelah seseorang melakukan pengindraan terhadap suatu objek tertentu, pengindraan terjadi melalui panca indera manusia yakni: penglihatan, pendengaran, penciuman, rasa dan raba.

Menurut asumsi peneliti, berdasarkan hasil penelitian yang diperoleh dari 62 orang responden yang diteliti mayoritas berpengetahuan kurang, jadi semakin rendah pengetahuan orang maka akan membuat seseorang bersikap lebih lambat dan lebih sulit memahami serta menambah wawasan pengetahuan tentang manfaat imunisasi pilihan dan juga sebaliknya semakin tinggi pengetahuan seseorang maka akan membuat seseorang membuat bersikap lebih cepat dan lebih mudah memahami serta menambah wawasan pengetahuan tentang manfaat imunisasi pilihan.

Hasil penelitian berdasarkan umur responden dapat di lihat bahwa mayoritas responden yang berpengetahuan kurang umur $>30$ tahun sebanyak 35 orang $(56,45 \%)$ dan minoritas responden berpengetahuan baik umur 20-30 tahun sebanyak 1 orang (1,61\%). Menurut (Notoadmodjo, 2005) umur adalah lamanya hidup seseorang sejak dilahirkan hingga saat ini dalam satu tahun. Daya ingat seseorang salah satunya dipengaruhi oleh umur, maka dapat disimpulkan bahwa bertambahnya umur seseorang dapat berpengaruh pada pertambahan pengetahuan yang diperolehnya. Dimana semakin tua umur seseorang maka semakin tinggi pengetahuan yang diperoleh, pembagian umur tersebut antara lain: $<20$ tahun, 20-35 tahun dan $>35$ tahun.

Umur dengan tingkat pengetahuan dapat berkaitan dan merupakan suatu patokan, dimana dari hasil penelitian penulis mengasumsikan bahwa hal ini sebabkan karena pengalaman responden dalam usia tersebut terhadap imunisasi pilihan masih kurang dan juga responden merasa bahwa anak- anaknya yang sudah mulai besar tidak lagi mendapatkan imunisasi. Berdasarkan pekerjaan responden dari hasil penelitian mayoritas responden yang berpengetahuan kurang adalah Petani sebanyak 24 orang (38,71\%) dan minoritas responden berpengetahuan baik adalah Petani sebanyak 1 orang (1,61\%). Menurut (Sukarto dalam Rhezmi, 2007) pekerjaan berhubungan dengan sosial ekonomi seseorang dipengaruhi oleh pengetahuan selanjutnya dinyatakan bahwa pekerjaan merupakan kegiatan-kagiatan yang dilakukan sehari-hari dalam kaitannya untuk mendapatkan penghasilan dari pekerjaan.

Menurut asumsi peneliti, adanya kekurangan pengetahuan responden yang kebanyakan sebagai petani dikarenakan kurang memperoleh informasi baik dari media cetak, media elektronik maupun ditempat pelayanaan kesehatan, dimana responden sibuk untuk mencari kebutuhan sehari -hari sehingga waktu untuk mendapatkan informasi mengenai imunisasi pilihan sangat kurang. Berdasarkan pendidikan responden dari hasil penelitian mayoritas responden yang berpengetahuan kurang adalah berpendidikan SD sebanyak 30 orang $(48,39 \%)$ dan minoritas responden berpengetahuan cukup adalah SMP/SMA sebanyak 3 orang $(4,84 \%)$.

Menurut (Notoadmodjo, 2003) bahwa tingkat pendidikan merupakan salah satu factor yang mempengaruhi persepsi seseorang, lebih mudah menerima ide-ide dan teknologi. Adapun tujuan yang hendak dicapai melalui pendidikan adalah untuk mengubah (pengertian, pendapat, konsep-konsep), sikap dan persepsi serta menanamkan tingkah laku atau kebiasaan yang baru.

Dengan pendidikan tinggi maka seseorang akan cenderung untuk mendapatkan informasi, baik dariorang lain maupun dari media massa. Pengetahuan sangat erat kaitannya dengan pendidikan dimana diharapkan seseorang dengan pendidikan tinggi, maka orang tersebut akan semakin luas pula pengetahuannya. Pendidikan memiliki peranan penting dalam menentukan kualitas manusia. Dengan pendidikan manusia dianggap akan memperoleh pengetahuan dan implikasinya.

Dari hasil penelitian penulis mengasumsikan bahwa hal ini mungkin disebabkan oleh pendidikan responden yang rendah yaitu hanya SD, jadi sulit menerima ide-ide, ilmu pengetahuan dan teknologi yang baru, serta keinginan dan minat untuk hidup sehat sangat kecil dibanding dengan pendidikan Perguruan Tinggi yang mudah menerima ide-ide tentang pengetahuan dibidang kesehatan terutama tentang imunisasi yang dianjurkan.

Berdasarkan sumber informasi dari hasil penelitian dapat diketahui bahwa mayoritas responden yang berpengetahuan kurang adalah memperoleh informasi dari keluarga/lingkungan sebanyak 26 orang $(41,94 \%)$ dan minoritas responden berpengetahuan cukup memperoleh informasi dari petugas kesehatan sebanyak 2 orang $(3,22 \%)$.

Menurut (Notoadmodjo, 2006) bahwa informasi yang diperoleh dari berbagai sumber akan mempengaruhi sesorang, bila seseorang memperoleh informasi maka ia cenderung memiliki pengetahuan yang lebih luas. Sumber informasi adalah sesuatu yang menjadi perantara dalam menyampaikan informasi, merangsang pikiran dan kemampuan, informasi yang diperoleh dari berbagai sumber akan mempengaruhi tingkat pengetahuan seseorang bila seseorang memperoleh informasi maka ia akan cenderung mempunyai pengetahuan yang lebih luas.

Asumsi peneliti dalam penelitian ini, dimana rata-rata responden mendapatkan informasi dari keluarga saja karena kurang bergaul dengan tenaga kesehatan dan juga informasi-informasi tentang kesehatan 
baik dari media cetak maupun dari media elektronik dan hal ini dapat menyebabkan berkurangya pengetahuan mereka mengenai kesehatan termasuk masalah tentang imunisasi pilihan.

\section{CONCLUSION}

Setelah dilakukan penelitian disimpulkan bahwa pengetahuan ibu tentang imunisasi yang dianjurkan masih kurang. Diharapkan kepada ibu-ibu yang mempunyai balita agar lebih aktif lagi dalam mencari informasi tentang imunisasi pilihan melalui tenaga kesehatan, media elektronik, media masa dan media cetak.

\section{REFERENCES}

Meriam, Andi. 2009. Asuhan Neonatus Bayi dan Balita. Jakarta: Buku Kedokteran EGC.

Maryunani, Anik. 2010. Ilmu Kesehatan Anak Dalam Kebidanan, Depnaker: Trans Info Media.

Anonim. 2008. Pendekatan Imunisasi Menuju Sehat. Bandung: Citra Aji Pratama.

Atikah. 2014. Imunisasi dan Vaksinasi. Yogyakarta: Nuha Medika.

Ranuh, I.G.N. Gde, dkk. 2011. Pedoman Imunisasi Di Indonesia. Yogyakarta: Ikatan Dokter Anak Indonesia. Iren. 2013. Gambaran Pengetahuan Ibu Tentang Imunisasi Pilihan 2013, 1, http://florentinaja.blogspot.co.id/2013/11/gambaran pengetahuan ibu tentang. html di peroleh pada 03 Desember 2016.

Lisnawati, Lilis. 2013. Generasi Sehat Melalui Imunisasi. Jakarta: Trans Info Media.

Notoatmodjo, S. 2008. Metodologi Penelitian Kesehatan. Jakarta: Rineka Cipta.

Soekidjo. 2010. Metodologi Penelitian Kesehatan. Jakarta: Rineka Cipta.

Sugiyono. 2010. Metode Penelitian Kuantitatif Kualitati Dan R\&D. Bandung: Alfabeta.

Robin, Dompas. 2010. Sistem Imun, Imunisasi dan Penyakit Imun. Jakarta: Widya Medika.

Ronald, H.S. 2011. Generasi Sehat Melalui Imunisasi. Jakarta: Trans Info Media.

Muslihatun, Wafi Nur. 2010. Asuhan Neonatus Bayi Dan Balita. Yogyakarta: Citramaya.

Soetjiningsih. 1995. Pengertian Berat Badan. https://pengertianberatbadan.wordpress.com/. di diperoleh 19 Oktober 2016.

Suparyanto. 2010. Pengertian berat badan http://dr-suparyanto.blogspot.co.id/2010/12/pengaruh-kb-suntikterhadap-perubahan.html, diproleh tanggal 22 Oktober 2016.

Surono, C. 2009. Pengertian Berat Badan. https://pengertianberatbadan.wordpress.com/diakses tanggal 19 oktober 2016.

Udin, S. Winataputra. 2004. Pengertian Variasi. http://ghufron-dimyati.blogspot.co.id, diperoleh tanggal 05 November 2016.

Yanti. 2014. Buku Ajar Kesehatan Reproduksi Untuk Mahasiswi Kebidanan. Yogyakarta: Pustaka Rihama.

\section{BIOGRAPHIES OF AUTHORS}

\begin{tabular}{l|l|} 
Nova Linda Rambe, Gelar D-III diperoleh dari Akademi Kebidanan Darmo, Jurusan \\
Kebidanan pada tahun 2009. Gelar D-IV diperoleh dari Universitas Padjadjaran, \\
Jurusan Kebidanan Tahun 2011. Magister Kebidanan diperoleh dari Universitas \\
Padjadjaran, Jurusan Kebidanan pada tahun 2017. Saat ini aktif sebagai dosen tetap di \\
Prodi S1 Kebidanan Universitas Imelda Medan dan menjabat sebagai Ketua Program \\
Studi.
\end{tabular}

